\title{
Yellow Garden Spider, Writing Spider Argiope aurantia (Lucas) (Arachnida: Araneae: Araneidae) ${ }^{1}$
}

Taryn B. Griffith and Jennifer L. Gillett-Kaufman²

\section{Introduction}

Most commonly known as the yellow garden spider, Argiope aurantia Lucas is a large orb-weaving spider. Argiope aurantia is also known as the writing spider due to the trademark vertical zig-zag pattern they construct in their webs (Enders 1973). The yellow garden spider is a common species that frequently captures the attention of gardeners due to their zig-zag web, striking black and white (or yellow) pattern, and relatively large size (Figure 1). Although their appearance may cause alarm, this species is relatively harmless and will generally flee rather than attack when disturbed (Enders 1973).

\section{Distribution}

Argiope aurantia resides in Central and North America and is most common in the eastern portion of its range (Levi 1968). They occur in a variety of habitats such as along edges of water bodies, grassy hillsides (Levi 1968), and woodlands (Fitch 1963). The highest densities of Argiope aurantia occur at edge habitats, or where two different habitats meet (Enders 1973). The yellow garden spider frequently is observed in areas disturbed by human development, such as roadsides, farms, and gardens (Enders 1973).

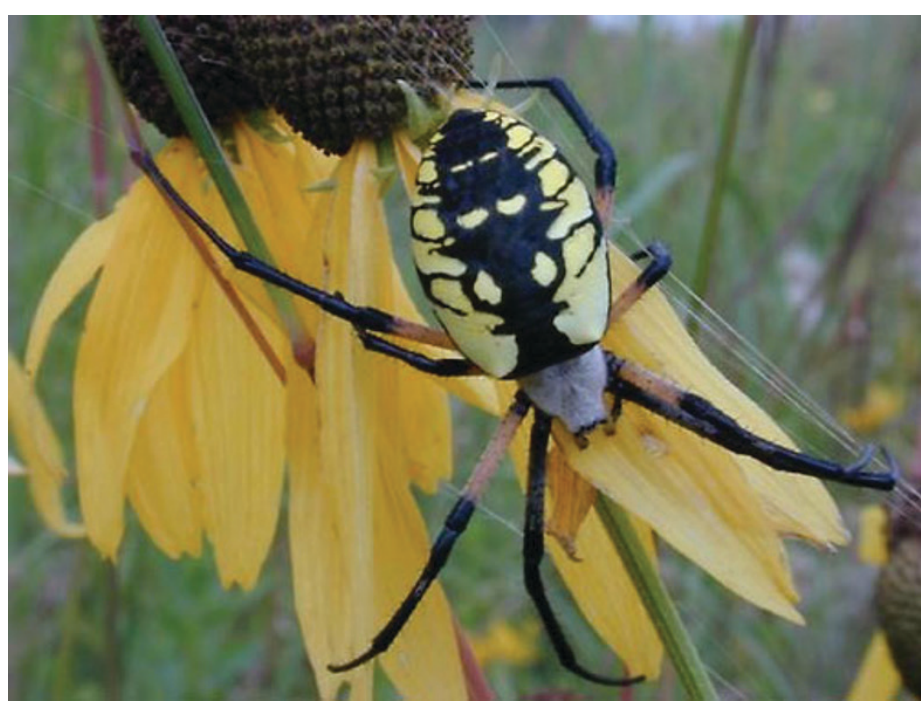

Figure 1. Adult female Argiope aurantia (Lucas).

Credits: Dennis Profant, www.bugguide.net

\section{Description}

\section{Eggs}

Yellow garden spider eggs are spherical and range in color from white to light brown. Eggs are placed in white multilayered tear drop shaped egg sacs, suspended within the spider's web. These egg sacs are made of a flocculent (wool like) layer of silk used to buffer the eggs and spiderlings from any potential short-term fluctuations of temperature (Figure 2). This flocculent layer is located between the spiderlings and the shell, or outer layer, of the egg sac

1. This document is EENY-743, one of a series of the Entomology and Nematology Department, UF/IFAS Extension. Original publication date October 2019. Visit the EDIS website at https://edis.ifas.ufl.edu for the currently supported version of this publication. This document is also available on the Featured Creatures website at http://entomology.ifas.ufl.edu/creatures.

2. Taryn B. Griffith, Horticultural Sciences Department; and Jennifer L. Gillett-Kaufman, Extension scientist, Entomology and Nematology Department; UF/IFAS Extension, Gainesville, FL 32611.

The Institute of Food and Agricultural Sciences (IFAS) is an Equal Opportunity Institution authorized to provide research, educational information and other services

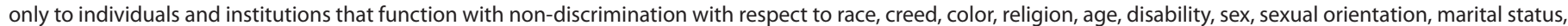

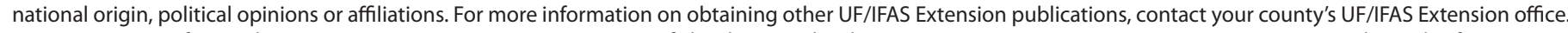
U.S. Department of Agriculture, UF/IFAS Extension Service, University of Florida, IFAS, Florida A \& M University Cooperative Extension Program, and Boards of County Commissioners Cooperating. Nick T. Place, dean for UF/IFAS Extension. 
(Hieber 1985). The yellow garden spider preferentially attaches egg sacs to webbing underneath vegetation or under the coverage of broad-leaved plants (Hieber 1985).

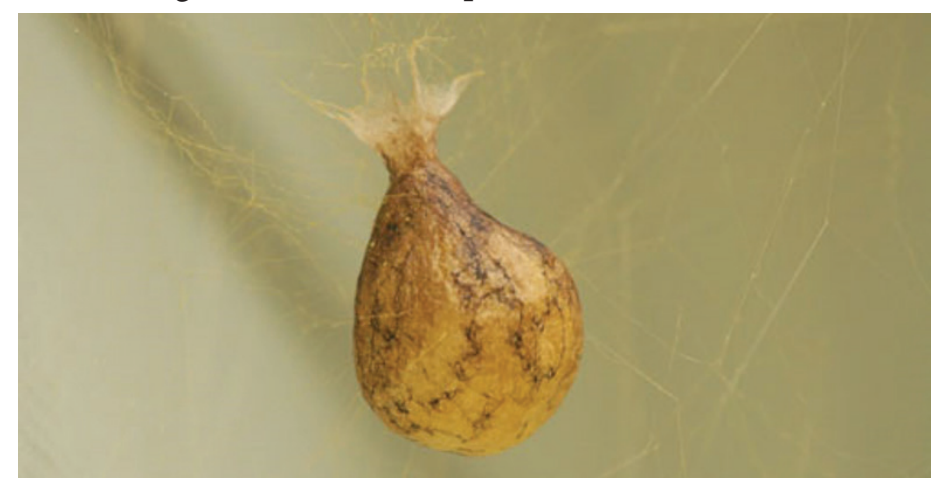

Figure 2. Light brown egg sac of the yellow garden spider, Argiope aurantia (Lucas).

Credits: Lyle J. Buss, UF/IFAS

\section{Juveniles}

Juveniles are smaller than adults and differ in color. Unlike the solid black legs found on adults, juvenile Argiope aurantia have orange and black banded legs (Howell and Ellender 1984) (Figure 3). Argiope aurantia have larger webs as they mature; for graphs detailing the web size to spider weight ratio of juvenile spiders please refer to Howell and Ellender (1984). Unfortunately these authors did not outline the length or width of the spiders they sampled, they relied on a weight to indicate spider size.

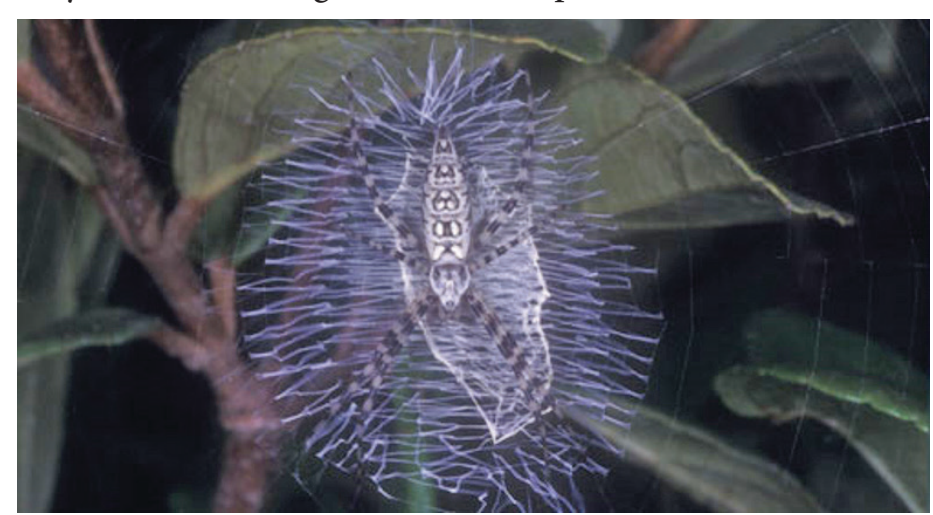

Figure 3. Immature female Argiope aurantia (Lucas) is camouflaged against the thicker web filaments referred to as stabilimentum. Credits: Lyle J. Buss. UF/IFAS

Juvenile Argiope aurantia disperse away from the location of their egg sac in springtime (Enders 1973). Like many spiders, juvenile Argiope aurantia disperse by catching wind currents on silk they release, commonly known as ballooning. Younger spiders typically balloon vertically and begin to balloon horizontally as they mature due to their increased size. Adults are too large to balloon.

\section{Adults}

Adults are sexually dimorphic, meaning that males and females have different forms. Most noticeably, males are smaller (less than $6 \mathrm{~mm}$ ) than females (14 to $24 \mathrm{~mm}$ ) (Levi 1968) (Figure 4). Females also have characteristic bands of yellow and black on their carapace, the frontal hardened exoskeleton on top of the spider and the eyes are covered with silver hairs, while males are brown (Harwood 1974). Male and female yellow garden spider also can be distinguished from each other by the size of their pedipalps (appendages located before the first pair of walking legs). Males have enlarged, swollen pedipalps (Howell and Ellender 1984).

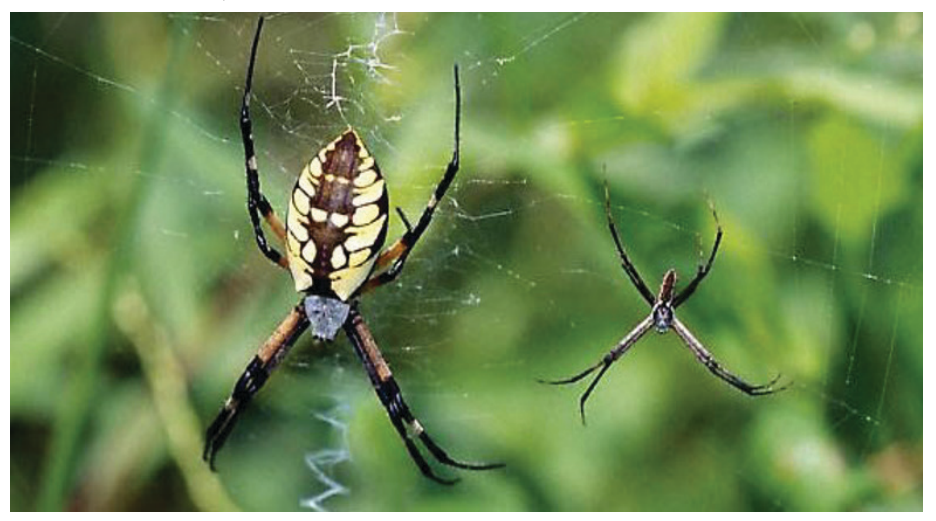

Figure 4. Female (left) and male (right) Argiope aurantia (Lucas). Credits: Troy Bartlett, www.bugguide.net

\section{Web Building Behavior}

Initially, webs tend to be placed in areas sheltered from wind and are around $15 \mathrm{~cm}$ from the ground. As spiders age, the preference for higher web placement increases (Enders 1977). Starting with males of the sixth instar and females of the twelfth instar, there is no longer a noticeable preference to shield the webs from winds (Enders 1977). Fourth instar juveniles show a preference towards placing their webs directed towards a light source (Enders 1997).

Yellow garden spiders are crepuscular (active during the morning and at nightfall) (Harwood 1974). Juveniles construct webs at night similar to adults, but second and third instars are slow to complete their webs, requiring two nights, rather than a typical single night (Enders 1977). Webs are typically attached to trees, shrubs, and herbaceous weeds; however, Lespedeza spp., or bush clover are a preferred attachment site (Enders 1997). Webs are primarily placed facing away from dense vegetation and angled downhill. Adults prefer to place their webs at high points on vegetation and in areas new to the spider, they exhibit questing behavior where they climb to the top of the vegetation and wave their front legs to survey the area. 


\section{Hosts}

The yellow garden spider has been observed catching and feeding primarily on the orders Odonata (dragonflies and damselflies) and Hymenoptera (wasps and bees). Although less frequently, prey in the orders Diptera (flies), Ephemeroptera (mayflies), Coleoptera (beetles), Hemiptera (true bugs), Orthoptera (grasshoppers), and Lepidoptera (butterflies and moths) have been observed in webs (Howell and Ellender 1984).

Spiders seen at rest on the hub or center of the web are feeling for vibrations from intruders or prey (Harwood 1974). When prey is caught, the spider waits until they are no longer moving and pull at the radii (silks of the web that project from the center) to find where the prey have been captured (Harwood 1974). The prey is then wrapped in silk during a process called throwing (Harwood 1974). Orthopterans (grasshoppers and crickets) are the most frequent prey item to be wrapped by the throwing method (Figure 5). Alternatively, Argiope aurantia may wrap the prey in another technique called rotational swathing, where the prey is wrapped by the spider rotating and attaching silk to the prey simultaneously (Harwood 1974). The last method is called walking swath, where the spider walks over and around the prey to bind it in silk (Harwood 1974). After the prey is secured, the spider will envenomate them by biting and injecting venom into the prey, killing them and liquefying their internal organs for consumption (Harwood 1974).

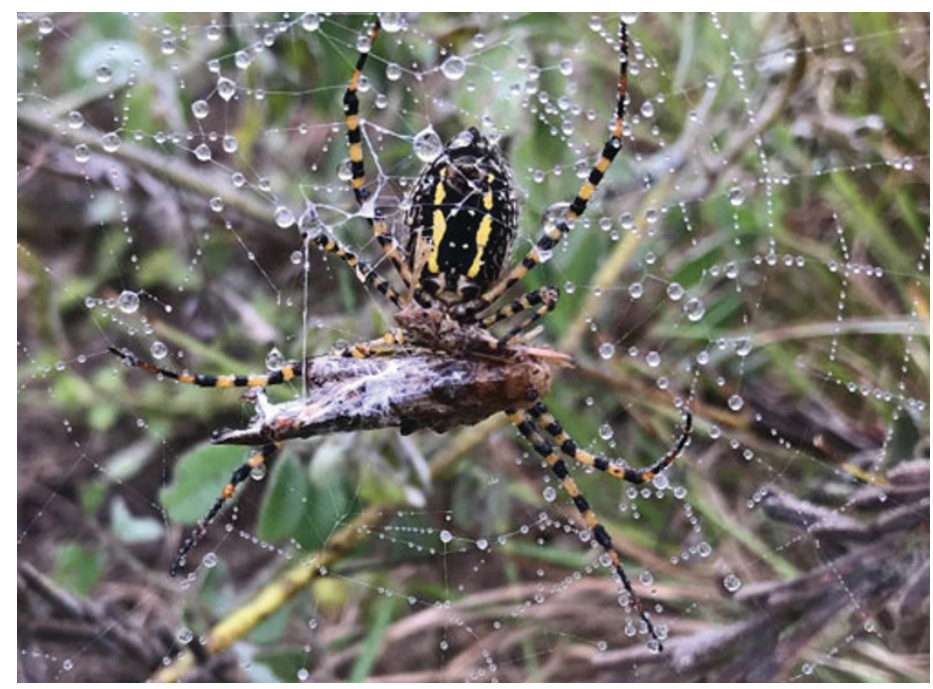

Figure 5. A female Argiope aurantia (Lucas) using the throwing method to secure an Orthopteran (grasshopper) host.

Credits: Jennifer L. Gillett-Kaufman, UF/IFAS

\section{Enemies}

Smaller, younger Argiope aurantia are susceptible to attacks from salticid spiders, commonly known as jumping spiders (Tolbert 1975). Due to their large size, adult Argiope aurantia attacks by salticid spiders are often deterred and salticids may even be preyed upon if caught in the web (Tolbert 1975). Mud daubers will commonly prey on Argiope aurantia. In response to their own predators, Argiope aurantia will create up to two barrier webs within their primary orb web. Barrier webs serve as a physical barrier to some predators by preventing easy access onto the web. Barrier webs are placed on the exterior edges of the orb and more importantly serve to alert the spider of any disturbances in the web (Tolbert 1975).

Yellow garden spiders construct stabilimenta, a thicker opaque silk, in their webs defensively. When provoked, the spider may flex the stabilimentum to threaten the intruder (Tolbert 1975) or eject itself from its web and onto nearby vegetation or the ground, making them difficult to catch by predators or humans (Enders 1973).

\section{Selected References}

Enders, F. 1997. "Web-site selection by orb-web spiders, particularly Argiope aurantia Lucas." Animal Behavior 25: 694-712.

Enders, F. 1973. "Selection of the habitat by Argiope aurantia Lucas (Araneidae)." The American Midland Naturalist 90: 47-55.

Fitch, H. A. 1963. "Spiders of the University of Kansas Natural History Reservation and Rockefeller Experimental Tract." University of Kansas Natural History Museum Publication 33: 1-202.

Harwood, R. 1974. "Predatory behavior of Argiope aurantia (Lucas).” The American Midland Naturalist 91: 130-139.

Hieber, C. 1985. "The "insulation" layer in the cocoons of Argiope aurantia (Araneae: Araneidae)." Journal of Thermal Biology 10: 171-175.

Howell, F., and R. D. Ellender. 1984. "Observations on growth and diet of Argiope aurantia Lucas (Araneidae) in a successional habitat." The Journal of Arachnology 12: 29-36.

Levi, H. W. 1968. "The spider genera Gea and Argiope in America (Araneae: Araneidae)." Bulletin Museum of Comparative Zoology 136: 319-352.

Tolbert, W. 1975. "Predator avoidance behaviors and web defense structures in the orb weavers Argiope aurantia and Argiope trifasciata (Araneae, Araneidae)*." Psyche 92: 29-52. 